\title{
PENGARUH PENGGUNAAN MODEL PEMBELAJARAN PRATIKUM MELALUI PENDEKATAN DISCOVERY BERBASIS INKUIRI DAN GAYA KOGNITIF TERHADAP HASIL BELAJAR SISWA
}

\section{THE INFLUENCE OF USING THE PRACTICAL LEARNING MODEL THROUGH DISCOVERY BASED INQUIRY AND COGNITIVE STYLE APPROACHES IN STUDENST LEARNING OUTCOMES}

\author{
Eko Sugiarto*, Hartono, dan Subandowo \\ Program Studi Pascasarjana Teknologi Pendidikan Universitas PGRI Adibuana Surabaya, Surabaya, Indonesia \\ Email: ekosugiarto2603@gmail.com
}

Diterima: 13 September 2019. Disetujui: 17 September 2019. Dipublikasikan: 3 Maret 2020

\begin{abstract}
Abstrak: Pemilihan model atau metode pembelajaran yang sesuai untuk materi pelajaran tertentu, karakteristik materi pelajaran, dan karakteristik peserta didik (gaya kognitif) terhadap pencapaian hasil belajar. Penelitian eksperimen ini dengan desain treatment by level 2x2. Sampel yang digunakan dalam penelitian ini yaitu 2 kelas eksperimen dan 2 kelas kontrol, masing-masing kelas berjumlah 38 peserta didik baik dari SMP Negeri 17 Surabaya maupun dari SMP Negeri 16 Surabaya, yang secara empirik dipandang cukup homogen serta memiliki karakter yang relatif sama. Instrumen yang digunakan terdiri dari 2 instrumen yaitu (1) instrumen untuk mengukur gaya kognitif dan (2) instrumen untuk mengukur hasil belajar. Instrumen yang pertama adalah Group Embedded Figures Test (GEFT) untuk mengukur gaya kognitif, sedangkan instrument yang kedua adalah tes pengetahuan awal (pre-test) dan setelah perlakuan (post-test) yang terdiri dari 20 soal pilihan ganda. Hasil penelitian menunjukkan bahwa nilai probabilitas signifikansi < 0,05 maka kesimpulan H0 ditolak dan H1 diterima. Hal ini terbukti; (1) Ada perbedaan antara model pembelajaran pratikum melalui pendekatan discovery berbasis inkuiri dengan model pembelajaran pratikum tanpa melalui pendekatan discovery berbasis inkuiri pada materi sistem gerak pada manusia terhadap hasil belajar kelas 8 pada tahun pelajaran 2018-2019 di SMP Negeri 17 dan SMP Negeri 16 Surabaya; (2) Ada perbedaan antara gaya kognitif tinggi atau field Independence (FI) dan gaya kognitif rendah atau dependence (FD) pada materi sistem gerak pada manusia terhadap hasil belajar kelas 8 pada tahun pelajaran 2018-2019 di SMP Negeri 17 dan SMP Negeri 16 Surabaya; (3) Ada interaksi antara model pembelajaran pratikum melalui pendekatan discovery berbasis inkuiri dan gaya kognitif terhadap hasil belajar kelas 8 pada tahun pelajaran 2018-2019 di SMP Negeri 17 dan SMP Negeri 16 Surabaya.
\end{abstract}

Kata Kunci: Praktikum, Discovery berbasi inkuiri, gaya kognitif, sistem gerak manusia

\begin{abstract}
The selection of models or learning methods that are appropriate for certain subject matter, the characteristics of the subject matter, and the characteristics of students (cognitive style) towards the achievement of learning outcomes. The experimental research with treatment design by level $2 \times 2$. The samples used in this study are two experimental classes and two control classes, each class consists 38 learners both from Public Junior High School 17 Surabaya and Public Junior High School 16 Surabaya who are empirically considered fairly homogeneous and have relatively similar character. The instrument used consists of two instruments namely (1) an instrument for measuring cognitive style and (2) instrument for measuring learning outcomes. The first instrument is the Group Embedded Figures Test (GEFT) which to measure cognitive style. Meanwhile, the second instrument is a test of preliminary knowledge (pre-test) and further treatment (post-test) which consist of 20 multiple choice questions. The results show that the probability value is significant $<0.05$, then the conclusion $\mathrm{H} 0$ is rejected and $\mathrm{H} 1$ is accepted. This is proven that (1) There is a difference between practical learning modal through inquiry-based practical learning model without through inquiry-based discovery approaches on the material of human motion system towards the learning outcomes of the $8^{\text {th }}$ grade in the school year 2018-2019 in Public Junior High School 17 Surabaya; (2) There is a difference between high cognitive styles or Field Independence (FI) from low cognitive style or Field Dependence (FD) on the material of human motion system towards the learning outcomes of the $8^{\text {th }}$ grade in the school year 2018-2019 in Public Junior High School 17 Surabaya and Public Junior High School 16 Surabaya; (3) There is an interaction between practical learning model through inquiry-based discovery approaches and cognitive style towards practical learning model of the $8^{\text {th }}$ grade in the school year 2018-2019 in Public Junior High School 17 Surabaya and Public Junior High School 16 Surabaya.
\end{abstract}

Key words : Practice, discovery-based inquiry learning, cognitive style, human motion system

\section{PENDAHULUAN}

Guru yang mengajar IPA pada

Kurikulum 2013 dituntut menggunakan model pembelajaran Saintifik, beberapa model, srategi, atau metode pembelajaran yang diterapkan dengan mengintegrasikan elemen-elemen pendekatan 
santifik dalam pembelajaran. Metode yang sesuai dengan pendekatan pembelajaran santifik antara lain: Pembelajaran berbasis inkuiri, pembelajaran penemuan (discovery learning), pembelajaran berbasis masalah (problem based learning), dan pembelajaran berbasis proyek (project based learning), dan metode lain yang relevan. Pertimbangan dalam pemilihan model atau metode pembelajaran yang sesuai, untuk materi pelajaran tertentu juga terkait dengan karakteristik materi pelajaran [1].

Pembelajaran berbasis inkuiri adalah pembelajaran yang melibatkan siswa dalam merumuskan pertanyaan yang mengarahkan untuk melakukan investigasi dalam upaya membangun pengetahuan dan maknah baru, seperti didefinisikan Alberta Learning dalam Sani sebagai berikut [2].

Secara umum metode pembelajaran inkuiri merupakan metode yang dapat dipadukan dengan metode lainnya dalam sebuah pembelajaran. Metode inkuiri menekankan pada proses berbasis pada upaya menjawab pertanyaan dan menyelesaikan masalah berdasarkan fakta dan pengamatan. Aktivitas belajar melalui inkuiri tidak terlepas dari pengajuan pertanyaan yang terkait dengan permasalahan yang dikaji. Tahapan aktivitas belajar yang dilakukan dengan pembelajaran santifik tidak harus dilakukan mengikuti prosedur yang kaku, namun dapat disesuaikan dengan pengetahuan yang hendak dipelajari. Sedangkan discovery adalah menemukan konsep melalui serangkaian data atau informasi yang diperoleh melalui pengamatan atau percobaan [1]. Berdasarkan pemaparan di atas menurut penulis, belajar dengan menemukan (discovery) sebenarnya adalah bagian dari proses inkuiri atau pembelajaran discovery berbasis inkuiri. Kreaktifitas guru pada model pembelajaran saintifik sangat diperlukan, untuk lebih kreatif menciptakan situasi yang dapat membuat peserta didik belajar aktif untuk menemukan pengetahuan sendiri. Kegiatan belajar menggunakan metode discovery yang berbasis inkuiri pada umumnya melibatkan siswa dalam mengonstruksi pengetahuannya secara mandiri. Siswa diberi kesempatan untuk melakukan eksporasi, menjelaskan, melakukan elaborasi dan mengevaluasi proses dan produk belajarnya. Keberhasilan pendidik dalam proses pembelajaran sangat ditentukan sejauh mana ia memahami karakteristik peserta didiknya [3]. Kemampuan pendidik dalam hal ini sangat penting yaitu bagaimana pendidik mampu mengidentifikasi karakter-karakter masing-masing individu.

Perbedaan karakter tersebut berpengaruh besar terhadap belajar mereka sesuai dengan gaya atau cara mereka belajar masing-masing atau disebut dengan gaya kognitif dalam belajar, tentunya berbeda antara anak yang satu dengan yang lainnya. Tetapi pada kenyataannya sering penulis menjumpai baik guru maupun siswa banyak menemukan kesulitan dalam menterjemahkan model pembelajaran saintifik, khususnya saat kegiatan pratikum, pada materi gerak pada manusia, sehingga proses belajar mengajar kurang maksimal. Kebiasaan lama guru maupun siswa, dalam pelaksanaan proses pembelajaran pratikum di laboratorium (Lab) khususnya pada materi gerak pada manusia, sebelum datangnya kurikulum 2013 (K13) sulit untuk ditinggalkan, walaupun pelaksanaan K13 sudah berjalan beberapa tahun yang lalu, Karakteristik pembelajaran pratikum sebelum datangnya K13 yang biasa dilakukan di laboratorium saat kegiatan adalah: Siswa diberi lembar kerja siswa (LKS) untuk melaksanakan kegiatan pratikum, mengisi lembar kerja LKS, dikumpulkan hasil kerja pratikum, kemudian guru memberi penilaian lembar LKS yang telah dikumpulkan oleh siswa. Ini apabila dilakukan terus menerus setiap kegiatan pratikum IPA, dapat mengakibatkan kejenuhan, kurang semangat pada siswa dalam menjalankan pembelajaran pratikum IPA, sehingga hasil belajar siswa kurang optimal, khususnya pada saat pelaksanaan kegiatan pratikum gerak pada manusia.

Karakter mangacu pada sikap peserta didik yang berpengaruh terhadap kemampuan kognitif individu itu sendiri. Sikap bermula dari perasaan (suka atau tidak suka) yang terkait dengan kecenderungan seseorang dalam merespon sesuatu/objek. Sikap juga sebagai ekspresi dari nilainilai atau pandangan hidup yang dimiliki seseorang. Sikap dapat dibentuk, sehingga terjadinya prilaku atau tindakan yang diinginkan. Sikap terdiri dari tiga komponen, yakni: afektif, kognitif, dan konatif. Komponen afektif adalah perasaan yang dimiliki oleh seseorang atau penilaiannya terhadap suatu objek. Komponen kognitif adalah kepercayaan atau keyakinan seseorang mengenahi objek. Adapun komponen konatif adalah kecenderungan untuk berperilaku atau berbuat dengan cara-cara tertentu dengan berkenaan dengan objek sikap [4].

Gaya kognitif mempunyai bentuk-bentuk yang khas berdasarkan kemampuan intelektual seseorang yang ditampilkan dalam kegiatan konseptual dan kegiatan intelektual. Dengan bantuan kemampuan kognitif pebelajar dapat mencerna informasi melalui kegiatan intelektualnya. Untuk mengetahui gaya kognitif setiap orang, para pakar psikologi pembelajaran mengembangkan berbagai alat pengukurnya. Diantaranya adalah Group Embedded Figure Test (GEFT) yang membedakan kemampuan kognitif seseorang menjadi dua kelompok yaitu field independence $(F I)$ dan field dependence $(F D)$. Dalam GEFT subjek diminta untuk mengenali suatu bentuk gambar sederhana dari suatu pola kompleks di mana bentuk atau gambar sederhana dari suatu pola kompleks di mana bentuk atau gambar sederhana tersebut tersembunyi. Makin mudah seseorang mengenali bentuk-bentuk sederhana 
dalam pola-pola kompleks di mana bentuk-bentuk sederhana tersebut tersembunyi, berarti makin tinggi skor yang diperolehnya, maka ia dikatagorikan sebagai memiliki gaya kognitif fied independence. Sebaliknya, makin sulit seseorang mengenali bentuk-bentuk sederhana dari pola-pola kompleks di mana bentuk-bentuk sederhana tersebut tersembunyi, berarti makin rendah skor yang diperoleh, maka ia dikategorikan sebagai memiliki gaya kognitif fied dependence [5].

Menurut Al Darmono, bahwa gaya kognitif adalah cara yang disukai individu yang relatif tetap kaitannya dengan menerima, memproses informasi serta dalam memecahkan masalah yang sedang dihadapi. Jika individu cenderung mandiri dan tidak terpengaruh oleh situasi lingkungan dan sosial, maka termasuk katagori field independent. Sedangkan jika individu cenderung mengggantungkan pada lingkungan dan social, maka termasuk katagori field dependent [6]. Menurut Bruce Joyce dalam Riyana, gaya kognitif merupakan salah satu variabel kondisi belajar yang menjadi salah satu bahan pertimbangan dalam merancang pembelajaran [7].

Dengan demikian harapan penulis, pendekatan pembelajaran pratikum melalui pendekatan model pembelajaran discovery berbasis inkuiri dan gaya kognitif dapat membantu baik guru maupun siswa dalam menerjemahkan model pembelajaran saintifik pada kurikulum 2013, khususnya pada saat pratikum pada materi gerak pada manusia.

\section{METODE PENELITIAN}

Penulis menggunakan metode penelitian Eksperimental, yaitu memberikan perlakuan (treatment) kepada subjek, kemudian dilihat pengaruhnya dengan membandingkan rerata hasil skor tes prestasi dan post tes belajar [8]. Penelitian ini melibatkan dua sekolah yaitu SMP Negeri 17 dan SMP Negeri 16 Surabaya. Setiap sekolah diambil dua sampel kelas yang diberi perlakuan berbeda. Kelas yang satu menggunakan pendekatan metode discovery berbasis inkuiri yang dinyatakan sebagai kelas eksperimen, sedangkan kelas yang lain tanpa pendekatan metode discovery berbasis inkuiri yang dinyatakan kelas kontrol. Kedua kelas diberikan pretes, dan postes yang terdiri dari 20 soal pilihan ganda yang telah reliabel. diharapkan dapat mengukur hasil belajar siswa pada materi sistem gerak pada manusia, sebelum dan sesudah mendapatkan pengajaran. Rancangan penelitian ini dapat dilihat pada tabel 1 .

Tabel 1. Rancangan Penelitian

\begin{tabular}{lll}
\hline $\begin{array}{l}\text { Variabel (A) Bebas dan } \\
\text { Variabel (B) } \\
\text { Moderator }\end{array}$ & $\begin{array}{l}\text { Model pembelajaran } \\
\text { pratikum melalui } \\
\text { pendekatan discovery } \\
\text { berbasis inkuiri pada } \\
\text { materi sistem gerak pada } \\
\text { manusia }\end{array}$ & $\begin{array}{l}\text { Model pembelajaran } \\
\text { pratikum tanpa pendekatan } \\
\text { discovery berbasis inkuiri } \\
\text { pada materi sistem gerak } \\
\text { pada manusia }\end{array}$ \\
\hline $\begin{array}{l}\text { Gaya kognitif tinggi atau } \\
\text { field independence (FI) }\end{array}$ & A1B1 & A2B1 \\
$\begin{array}{l}\text { Gaya kognitif rendah atau } \\
\text { field dependence (FD) }\end{array}$ & A1B2 & A2B2 \\
\hline
\end{tabular}

Keterangan:

A1B1 : Kelompok siswa yang mendapat perlakuan Model pembelajaran pratikum melalui pendekatan discovery berbasis inkuiri dan gaya kognitif tinggi pada kelas eksperimen.

A1B2 : Kelompok siswa yang mendapat perlakuan Model pembelajaran pratikum melalui pendekatan discovery berbasis inkuiri dan gaya kognitif rendah pada kelas eksperimen.

A2B1 : Kelompok siswa yang mendapat perlakuan tanpa Model pembelajaran pratikum melalui pendekatan discovery berbasis inkuiri dan gaya kognitif tinggi pada kelas kontrol.

A2B2 :Kelompok siswa yang mendapat perlakuan Model pembelajaran pratikum tanpa pendekatan discovery berbasis inkuiri dan gaya kognitif rendah pada kelas kontrol.

Rancangan eksperimen yang digunakan adalah rancangan eksperimen dengan desain treatment by level $2 \times 2$, pemilihan metode ini didasarkan adanya perlakuan (treatment) [9]. Eksperimen diawali dengan pretes kemudian dilanjutkan dengan pemberian perlakuan dan diakhiri dengan posttes. Populasi dalam penelitian ini adalah seluruh siswa kelas 8 SMP Negeri 17 dan 16 Surabaya yang berjumlah 760 siswa.

Instrumen yang pertama adalah Group Embedded Figures Test (GEFT) untuk mengukur gaya kognitif [5]. pertimbangan menggunakan 
GEFT dalam penelitian ini sebagai berikut: (1) tes ini dilengkapi latian pada bagian awalnya, sehingga dapat mengejakan tes ini dengan jelas karena telah dilatih sebelumnya, (2) waktu yang dibutuhkan untuk mengerjakan tes ini cukup singkat (sembilan belas menit), dan tes ini mudah diadministrasikan, tidak memerlukan ketrampikan dan keahlihan khusus, dan tes ini valid dan reliabel karena sudah mengalami sejumlah pengujian.

Agar data dari hasil penelitian ini dapat dipertanggung jawabkan kebenarannya, maka dipergunakan metode analisis data secara statistik untuk membuktikan pengaruh dari variabel bebas terhadap variabel terikat, maka rumus yang digunakan Analisis varian (Anova) dua jalur dengan analisa SPSS 19 for Windows. Dalam analisis varian dua jalur dipakai untuk menguji data utama yaitu menguji signifikan pengaruh variabel bebas dan variabel moderator terhadap variabel terikat atau dengan kata lain untuk menguji pengaruh model pembelajaran discovery berbasis inkuiri dan gaya kognitif pada materi sistem gerak pada tubuh manusia terhadap peningkatan hasil belajar. Sebelum diadakan pengujian hipotesis, terlebih dahulu diadakan uji homogenitas data dan uji normalitas data.

\section{HASIL DAN PEMBAHASAN}

Hasil pengujian hipotesis penelitian terdiri dari 3 hipotesis dengan menggunakan software SPSS 19 for window dengan teknik analisis anova dua jalur adalah sebagai berikut:

\section{Hasil pengujian Hipotesis Pertama}

Pada tabel 2, diperoleh nilai Sig. sebesar 0,474 lebih besar dari 0,05. Hal ini menunjukkan bahwa tidak ada perbedaan varian antara kelompok penelitian, yaitu model pembelajaran pratikum melalui pendekatan discovery berbasis inkuiri dan model pembelajaran pratikum tanpa melalui pendekatan discovery berbasis inkuiri.

Diperoleh nilai Sig. sebesar 0,000 lebih kecil dari 0,05. Hal ini menunjukkan bahwa ada perbedaan antara model pembelajaran pratikum melalui pendekatan discovery berbasis inkuiri dengan model pembelajaran pratikum tanpa melalui pendekatan discovery berbasis inkuiri pada materi sistem gerak pada manusia terhadap hasil belajar kelas 8 pada tahun pelajaran 2018-2019 di SMP Negeri 17 dan SMP Negeri 16 Surabaya.

\section{Hasil pengujian Hipotesis Kedua}

Berdasarkan Tabel di atas, diperoleh nilai Sig. sebesar 0,104 lebih besar dari 0,05. Hal ini menunjukkan bahwa tidak ada perbedaan varian antara kelompok penelitian, yaitu gaya kognitif tinggi atau field Independence (FI) dan dan gaya kognitif rendah atau dependence (FD) terlihat pada tabel 3.

Berdasarkan Tabel 4 di atas, diperoleh nilai Sig. sebesar 0,018 lebih kecil dari 0,05. Hal ini menunjukkan bahwa ada perbedaan antara gaya kognitif tinggi atau field Independence (FI) dan dan gaya kognitif rendah atau dependence (FD) pada materi sistem gerak pada manusia terhadap hasil belajar kelas 8 pada tahun pelajaran 2018-2019 di SMP Negeri 17 dan SMP Negeri 16 Surabaya.

Tabel 2. Uji ANOVA Hasil Belajar Kelompok Eksperimen dan Kontrol

\begin{tabular}{lllllll}
\hline Hasil_Belajar & \multicolumn{6}{l}{} \\
& $\begin{array}{l}\text { Sum } \\
\text { Squares }\end{array}$ & \multicolumn{1}{l}{ of } & & & & \\
& df & Mean Square & F & Sig. \\
\hline Between Groups & 1095.158 & 1 & 1095.158 & 34.37 & .000 \\
& & & & 7 & \\
Within Groups & 4778.605 & 150 & 31.857 & & \\
Total & 5873.763 & 151 & & & \\
\hline
\end{tabular}

Tabel 3. Uji Homogenitas Gaya Kognitif FI dan FD

\begin{tabular}{llll}
\hline \multicolumn{4}{l}{ Test of Homogeneity of Variances } \\
\hline $\begin{array}{llll}\text { Hasil_Belajar } \\
\text { Levene Statistic }\end{array}$ & df1 & df2 & Sig. \\
2.671 & 1 & 150 & .104 \\
\hline
\end{tabular}


Tabel 4. Uji ANOVA Gaya Kognitif Terhadap Hasil Belajar

\begin{tabular}{llllll}
\hline Hasil_Belajar & & & & & \\
\hline & Sum & of & & & \\
& Squares & df & Mean Square & F & Sig. \\
Between Groups & 216.142 & 1 & 216.142 & 5.731 & .018 \\
Within Groups & 5657.621 & 150 & 37.717 & & \\
Total & 5873.763 & 151 & & & \\
\hline
\end{tabular}

\section{Hasil pengujian Hipotesis Ketiga}

Berdasarkan Tabel di atas, diperoleh nilai Sig. dari variabel interaksi model pembelajaran pratikum melalui pendekatan discovery berbasis inkuiri dengan hasil belajar adalah sebesar 0,042 lebih kecil dari 0,05 . Hal ini menunjukkan bahwa ada interaksi antara model pembelajaran pratikum melalui pendekatan discovery berbasis inkuiri dan gaya kognitif terhadap hasil belajar kelas 8 pada tahun pelajaran 2018-2019 di SMP Negeri 17 dan SMP Negeri 16 Surabaya.

\section{Hasil Pengujian Hipotesis}

1. Ada perbedaan antara model pembelajaran pratikum melalui pendekatan discovery berbasis inkuiri dengan model pembelajaran pratikum tanpa melalui pendekatan discovery berbasis inkuiri pada materi sistem gerak pada manusia terhadap hasil belajar kelas 8 pada tahun pelajaran 2018-2019 di SMP Negeri 17 dan SMP Negeri 16 Surabaya.

2. Ada perbedaan antara gaya kognitif tinggi atau field Independence (FI) dan dan gaya kognitif rendah atau dependence (FD) pada materi sistem gerak pada manusia terhadap hasil belajar kelas 8 pada tahun pelajaran 2018-2019 di SMP Negeri 17 dan SMP Negeri 16 Surabaya.

3. Ada interaksi antara model pembelajaran pratikum melalui pendekatan discovery berbasis inkuiri dan gaya kognitif terhadap hasil belajar kelas 8 pada tahun pelajaran 2018-2019 di SMP Negeri 17 dan SMP Negeri 16 Surabaya, dapat diperkuat seperti gambar di bawah ini.

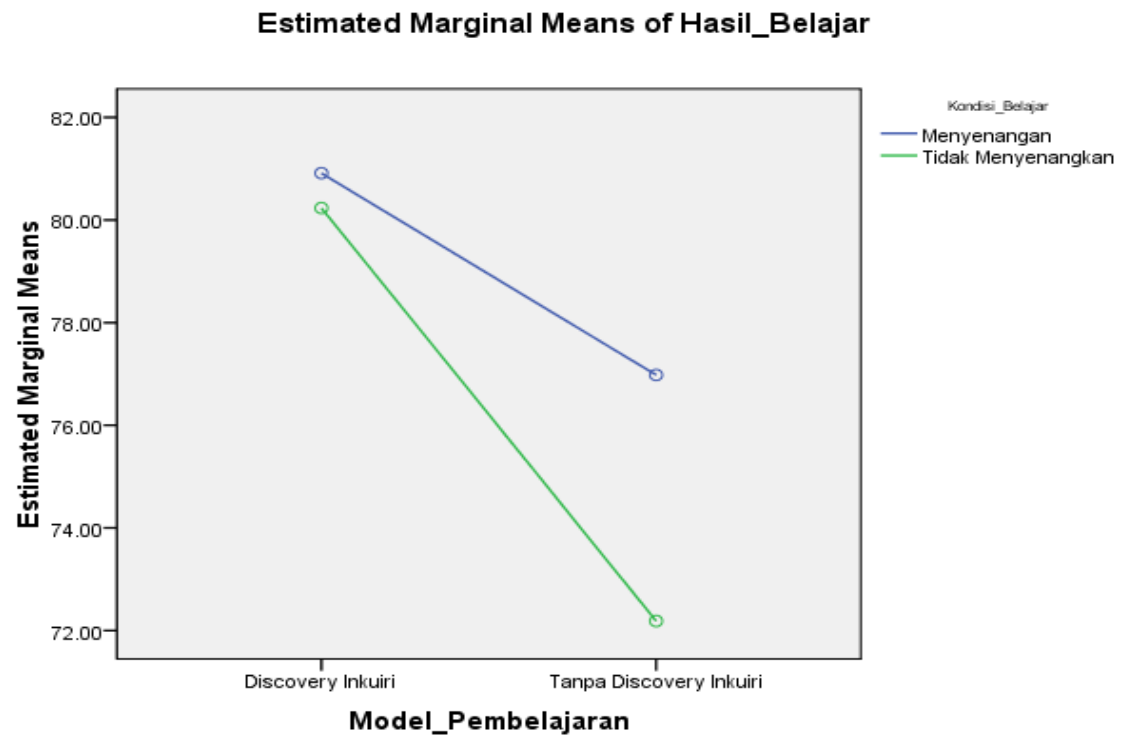

Gambar 1. Plot Interaksi.

\section{KESIMPULAN}

Berdasarkan hasil pengamatan terbukti bahwa terdapat perbedaan hasil belajar pada materi sistem gerak pada manusia yang diajar dengan penggunaan model pembelajaran pratikum melalui pendekatan discovery berbasis inkuiri dan diajar tanpa penggunaan model pembelajaran pratikum melalui pendekatan discovery berbasis inkuiri, di kelas 8 baik di SMP Negeri 17 Surabaya maupun di SMP Negeri 16 Surabaya pada tahun pelajaran 2018-2019. Terbuktinya hipotesis tersebut diperkuat adanya perbedaannya nilai rata-rata hasil belajar post-test pada materi sistem gerak pada manusia pada kelompok eksperimen (Penggunaan Model 
Pembelajaran Pratikum Melalui Pendekatan Discovery Berbasis Inkuiri) yang lebih tinggi sebesar 80,65 dari pada nilai rata-rata hasil belajar post-test pada kelompok kontrol (tanpa Penggunaan Model Pembelajaran Pratikum Melalui Pendekatan Discovery Berbasis Inkuiri).

\section{DAFTAR PUSTAKA}

[1] Sani, R. A. (2014). Pembelajaran saintifik untuk implementasi kurikulum 2013. Jakarta: PT Bumi Aksara.

[2] Ningsyih, S., Junaidi, E., \& Al Idrus, S. W. (2016). Pengaruh Pembelajaran Praktikum Berbasis Inkuiri Terbimbing Terhadap Kemampuan Berpikir Kritis Dan Hasil Belajar Kimia Siswa. Jurnal Pijar Mipa, 11(1).

[3] SUSANTI, Y. (2019). PENGARUH MODEL PEMBELAJARAN GUIDED INQUIRY TERHADAP KETERAMPILAN PROSES SAINS DAN HASIL BELAJAR KOGNITIF PESERTA DIDIK KELAS $X$ DI SMA NEGERI 1 JATI AGUNG LAMPUNG SELATAN.

[4] Hasanah, J., Jamaludin, J., \& Prayitno, G. H. (2019). Bahan Ajar IPA Berbasis Inkuiri Terstruktur Untuk Meningkatkan Literasi
Sains Peserta Didik SMP. Jurnal Pijar MIPA, 14(2), 18-24.

[5] Rufi'i, R. I. (2011). Pengaruh Strategi Pembelajaran dan Gaya Kognitif terhadap Perolehan Belajar Konsep dan Prosedur Statistika.(Disertasi). DISERTASI dan TESIS Program Pascasarjana UM.

[6] Aldarmono, A. (2012). Identifikasi Gaya Kognitif (Cognitive Style) Peserta Didik Dalam Belajar. Al-Mabsut: Jurnal Studi Islam dan Sosial, 3(1), 63-69.

[7] Ishak, M., Jekti, D. S. D., \& Sridana, N. (2017). Pengaruh Penerapan Pendekatan Saintifik Menggunakan Model Pembelajaran Discovery Dan Kooperatif Tipe Stad Terhadap Kemampuan Berpikir Kreatif Peserta Didik SDN 13 Ampenan. Jurnal Pijar Mipa, 12(1).

[8] Sudjana, N 2013. Tuntunan Penyusunan Karya Ilmiah Makalah-Skripsi-Tesis-Disertasi. Bandung: Sinar Baru Algensindo.

[9] Harjono, A. (2012). Perbedaan Strategi Pembelajaran dan Pemberian Advance Organizer Pengaruhnya Terhadap Hasil Belajar Fisika Siswa Kelas X. Jurnal Pijar MIPA, 7(1). 